\title{
Peach Rusty Spot Is Caused by the Apple Powdery Mildew Fungus, Podosphaera leucotricha
}

Tünde Jankovics, Plant Protection Institute of the Hungarian Academy of Sciences (PPI HAS), H-1525 Budapest, Hungary; Nenad Dolovac, Institute for Plant Protection and Environment, Department of Plant Pathology, 11000 Belgrade, Serbia; Aleksandra Bulajić and Branka Krstić, Institute of Plant Protection, Department of Phytopathology, University of Belgrade-Faculty of Agriculture, 11080 Belgrade, Serbia; Thierry Pascal, INRA, Unité de Génétique et d'Amélioration des Fruits et Légumes, UR1052, BP 94, F-84143 Montfavet, France; Marc Bardin and Philippe C. Nicot, INRA, Unité de Pathologie Végétale, UR0407, Domaine St. Maurice, BP 94, F-84140 Montfavet, France; and Levente Kiss, PPI HAS, Budapest, Hungary

\begin{abstract}
Jankovics, T., Dolovac, N., Bulajić, A., Krstić, B., Pascal, T., Bardin, M., Nicot, P. C., and Kiss, L. 2011. Peach rusty spot is caused by the apple powdery mildew fungus, Podosphaera leucotricha. Plant Dis. 95:719-724.

Peach rusty spot, an economically important disease of peach (Prunus persica var. persica), appears as necrotic spots on fruit. The etiology of the disease is still not well understood, although it has long been suspected that the causal agent is the apple powdery mildew pathogen, Podosphaera leucotricha. This work confirmed this hypothesis based on cross-inoculation experiments and analysis of rDNA internal transcribed spacer sequences polymerase chain reaction amplified from rusty spot and peach powdery mildew lesions. Cross-inoculations of apple and peach leaves with $P$. leucotricha and $P$. pannosa, the causal agent of peach powdery mildew, showed that (i) young peach fruit, up to $5 \mathrm{~cm}$ in diameter, developed symptoms typical of rusty spot follow-

ing inoculation with $P$. leucotricha; (ii) leaves of 'Jonagold' apple seedlings developed powdery mildew infections when inoculated by touching young rusty spot lesions to their surfaces; (iii) P. leucotricha sporulated on young peach fruit up to $5 \mathrm{~cm}$ in diameter; and (iv) peach leaves and young shoots were not susceptible to $P$. leucotricha, whereas $P$. pannosa infected all the green parts of peach. A field experiment revealed that there was only a 2 - to 3 -week period of time during early peach fruit development when the epidermis was susceptible to P. leucotricha. An outcome of this study is that now a clear distinction can be made between the symptoms caused by $P$. pannos $a$ and P. leucotricha on peach.
\end{abstract}

Rusty spot disease of peach (Prunus persica (L.) Batsch var. persica) results in development of necrotic spots on fruit, often covering large parts of their surfaces, and causing economic losses in peach production up to approximately $\$ 500 /$ ha (25). Yield losses result from a reduction of fruit quality. The disease was first described in Idaho in 1941 (1) and then from other parts of the United States $(7,8,26)$ and other countries $(9,10)$. Fungicide treatments were effective in disease management $(12,21)$ in spite of inconclusive information on the etiology of the disease. The apple powdery mildew fungus (Podosphaera leucotricha (Ellis \& Everh.) E.S. Salmon) was generally thought to be responsible for the symptoms $(8,12,13,19,21,26,27)$ but additional, unidentified causal agents were also suspected to play a role in this disease $(12,13,31)$. $P$. leucotricha was considered to be the rusty spot pathogen because the disease occurred mainly on peach trees planted close to apple orchards infected by $P$. leucotricha $(8,26,27)$ and powdery mildew mycelium was sometimes found on symptomatic peach fruit $(7,26)$. However, conclusive identification of the powdery mildew species detected in some studies on the rusty spots has not been reported. Moreover, absence of mycelium on these spots was also noted (31). The results of artificial inoculation of peach fruit with $P$. leucotricha were also contradictory: sometimes it resulted in symptom development (21) and sometimes not, despite repeated applications of the P. leucotricha inoculum (27). However, it is

Corresponding author: L. Kiss, E-mail: LKISS@ NKI.HU

* The e-Xtra logo stands for "electronic extra" and indicates that a supplementary figure is available online and that Figures 1 through 4 appear in color online.

Accepted for publication 13 February 2011.

doi:10.1094/PDIS-10-10-0711

(C) 2011 The American Phytopathological Society unclear whether the apparently successful inoculations (21) were conducted in isolation (8); thus, the role of external inocula cannot be excluded.

The main powdery mildew pathogen in peach orchards is $P$. pannosa (Wallr.) de Bary (syn. Sphaerotheca pannosa). Traditionally, this species has been divided into two varieties, S. pannosa var. persicae infecting peach and almond and $S$. pannosa var. rosae infecting rose (15); however, this separation has long been rejected $(2,20)$. The life cycle, pathogenesis, and epidemiology of $P$. pannosa on peach and nectarine are well known, similar to the symptoms of the primary and secondary infections caused by $P$. pannosa on peach leaves, shoots, and young fruit $(15,24)$. However, the role of $P$. pannosa in the development of peach rusty spot disease is uncertain.

Because morphology of the asexual stages of $P$. leucotricha and $P$. pannosa are similar (2), other evidence is needed to precisely identify the powdery mildew species occurring on the rusty spot lesions found on peach fruit. During the past 10 to 15 years, molecular markers, mainly nrDNA internal transcribed spacer (ITS) sequences, have commonly been used for such purposes $(6,16-$ $18,28,33,34)$, and these could be useful in this particular case, as well, because the ITS sequences of $P$. leucotricha and $P$. pannosa differ in more than 30 nucleotide positions (5).

Peach rusty spot has been a problem in Serbia since the late 1990 s, leading to substantial yield losses in late-maturing peach cultivars such as 'Summerset', 'Suncrest', and 'Fayette', with nearly all fruit becoming diseased in some orchards $(9,10)$. The main objectives of this study were to (i) determine whether $P$. leucotricha causes this disease, (ii) characterize the time of infection of peach fruit by $P$. leucotricha, and (iii) compare symptoms caused by $P$. leucotricha and $P$. pannosa on peach fruit and leaves.

\section{Materials and Methods}

Diseased peach materials. Peach fruit, 4 to $6 \mathrm{~cm}$ in diameter, exhibiting the symptoms of the rusty spot disease, were collected in Serbia in spring 2007, 2008, and 2009 (Table 1). Young peach 
and nectarine (Prunus persica (L.) Batsch var. nucipersica (Suckow) C.K. Schneid.) fruit and leaves exhibiting typical symptoms of powdery mildew were also collected in Serbian and French orchards in 2007 and 2008 (Table 1). Lesions identified as either rusty spot or powdery mildew, with a thin layer of the subtending tissue, were excised, then pressed and dried between paper towels to obtain dry plant materials which were stored as herbarium specimens for light microscopy and DNA studies. Some of these diseased plant materials were deposited at the Herbarium of the Martin Luther University (HAL), Halle, Germany and another part at the U.S. National Fungus Collections (BPI), Beltsville, MD (Table 1). Mature peach and nectarine fruit with typical symptoms of rusty spot or powdery mildew were also collected and examined.

Light microscopy. A subsample of the lesions identified as either rusty spot or powdery mildew based on symptoms was examined immediately after collection of diseased peach fruit in the field. Samples were removed with clear adhesive tapes, mounted on a microscope slide, and examined as such, or in water, or in cotton blue in lactophenol, using bright-field, dark-field, phasecontrast, and differential interference contrast (DIC) microscopy. Other samples were examined after being stored as dry materials following rehydration as described by Shin and $\mathrm{La} \mathrm{(29).}$

DNA extraction and polymerase chain reaction amplification of the rDNA ITS region. Total genomic DNA was extracted from small pieces of dried rusty spot and powdery mildew lesions using a Qiagen DNeasy Plant Mini Kit (Qiagen GmbH, Hilden, Germany). The ITS region of fungal rDNA was amplified by a nested polymerase chain reaction (PCR) with the primer set described by Cunnington et al. (6). The reaction components for the first PCR were $2 \mu \mathrm{l}$ of total genomic DNA, $2 \mu \mathrm{l}$ of incubation buffer (Fermentas, Lithuania), $2 \mu \mathrm{l}$ of $\mathrm{MgCl}_{2}$ ( $25 \mathrm{mM}$; Fermentas), $0.5 \mu \mathrm{l}$ of an equivalent mixture of each dNTP (10 mM each; Fermentas), 0.2 $\mu \mathrm{l}$ of each of the primers PMITS1 and PMITS2 (6) at $50 \mu \mathrm{M}$ each, 0.8 unit of Taq polymerase (Fermentas), and milliQ water up to a final volume of $20 \mu \mathrm{l}$. The PCR was performed with the following cycling parameters: an initial denaturation step at $94^{\circ} \mathrm{C}$ for $5 \mathrm{~min}$, followed by 35 cycles consisting of a denaturation step of $45 \mathrm{~s}$ at $94^{\circ} \mathrm{C}$, primer annealing for $45 \mathrm{~s}$ at $62^{\circ} \mathrm{C}$, and extension for $1 \mathrm{~min}$ at $72^{\circ} \mathrm{C}$. The final extension step was performed at $72^{\circ} \mathrm{C}$ for $10 \mathrm{~min}$. A negative control, where template DNA was replaced by milliQ water, was included for each set of reactions. PCR products were detected by electrophoresis in $1 \%(\mathrm{wt} / \mathrm{vol})$ agarose gel containing ethidium bromide and visualized and photographed over a UV light source. The components of the second PCR were identical to those of the first one, except that the fungal-specific primer pair ITS1F-ITS4 (14) was used instead of PMITS1 and PMITS2 primers. The cycling parameters were also identical, except that the primer annealing temperature was $55^{\circ} \mathrm{C}$. PCR products were purified using a PCR-M Clean Up System purification kit (Viogene, Hong Kong, China), then sequenced using a BigDye Terminator v3.1 Cycle Sequencing Kit (Applied Biosystems, Foster City, CA) according to the manufacturers' instructions. Both strands were sequenced with the ITS1F-ITS4 primer pair. Electrophoresis was carried out on an ABI PRISM 3100 Genetic Analyzer.

ITS sequence analysis. Sequences were compiled from electrophoregrams using Pregap4 and Gap4 (32) and deposited in GenBank. Alignments of homologous ITS sequences obtained from GenBank were made using Multalin (4). These were checked and manually edited with ProSeq 2.9 (11).

Inoculation of peach leaves and shoots with Podosphaera leucotricha and $P$. pannosa. To ensure that the peach trees used in these experiments were mildew free, 15 potted 1-year-old trees produced from rootstock 'GF305', known to be susceptible to $P$. pannosa (unpublished data), were kept in isolation for 1 month in a greenhouse compartment at a French National Institute for Agricultural Research (INRA) laboratory in Montfavet, France in spring 2008. Following this period, six peach trees were inoculated with $P$. leucotricha and six others with P. pannosa, whereas the remaining three plants served as water-inoculated controls. The $P$. leucotricha inocula used came from young apple shoots heavily infected with powdery mildew in an orchard located approximately $100 \mathrm{~km}$ from Montfavet. The shoots were transported to Montfavet and used for inoculations $6 \mathrm{~h}$ after they were collected from the field. The $P$. pannosa inocula were obtained from other potted peach trees used to maintain this pathogen in another greenhouse in Montfavet. To verify the viability of inocula, the germination of $P$. leucotricha and P. pannosa conidia was checked on the days when the inoculations were done on $1.5 \%$ water agar, as described previously (34).

For both powdery mildew species, three potted trees were inoculated by touching their leaves to infected apple and peach leaves, serving as sources of inocula, and the other three by blowing co-

Table 1. Host plants, places and dates of collection, herbarium accession numbers, and GenBank accession numbers (acc. no.) of the rDNA internal transcribed spacer (ITS) sequences of the powdery mildew samples obtained from peach and nectarine fruit and included in the molecular work ${ }^{\mathrm{a}}$

\begin{tabular}{|c|c|c|c|c|c|c|c|c|}
\hline $\begin{array}{l}\text { Sample } \\
\text { designation }\end{array}$ & Host plant & $\begin{array}{l}\text { Common name } \\
\text { of disease }\end{array}$ & $\begin{array}{l}\text { Place of } \\
\text { collection }\end{array}$ & $\begin{array}{l}\text { Date of } \\
\text { collection }\end{array}$ & $\begin{array}{c}\text { Visible } \\
\text { colonies }^{b}\end{array}$ & $\begin{array}{l}\text { Fungus } \\
\text { identity }^{c}\end{array}$ & $\begin{array}{l}\text { GenBank } \\
\text { acc. }^{\text {d }}\end{array}$ & $\begin{array}{l}\text { Herbarium } \\
\text { acc. }^{\mathrm{e}}\end{array}$ \\
\hline N3-08 & $\begin{array}{l}\text { Podosphaera persica } \\
\text { var. persica 'Fayette' }\end{array}$ & Rusty spot & Bela Crkva, Serbia & 7 June 2008 & No & P. leucotricha & HM579838 & HAL 2384F \\
\hline N4-08 & $\begin{array}{l}\text { P. persica var. persica } \\
\text { 'O'Henry' }\end{array}$ & Rusty spot & $\begin{array}{l}\text { Novi Slankamen, } \\
\text { Serbia }\end{array}$ & 9 June 2008 & No & P. leucotricha & HM579839 & BPI 880514 \\
\hline N5-08 & $\begin{array}{l}\text { P. persica var. persica } \\
\text { 'Summerset' }\end{array}$ & Rusty spot & $\begin{array}{l}\text { Selo Vinča-Topola, } \\
\text { Serbia }\end{array}$ & 10 June 2008 & No & P. leucotricha & HM579840 & HAL 2383F \\
\hline N6-08 & $\begin{array}{l}\text { P. persica var. persica } \\
\text { 'Summerset' }\end{array}$ & Rusty spot & Radmilovac, Serbia & 19 June 2008 & No & P. leucotricha & HM579841 & BPI 880513 \\
\hline $\mathrm{P} 1$ & $\begin{array}{l}\text { P. persica var. } \\
\text { nucipersica }\end{array}$ & Powdery mildew & Male Pijace, Serbia & 18 August 2007 & Yes & P. pannosa & HM579846 & ... \\
\hline $\mathrm{P} 2$ & $\begin{array}{l}\text { P. persica } \text { var. } \\
\text { nucipersica }\end{array}$ & Powdery mildew & $\begin{array}{l}\text { INRA, Gotheron, } \\
\text { France }\end{array}$ & 6 May 2008 & Yes & P. pannosa & HM579842 & BPI 880511 \\
\hline P3 & $\begin{array}{l}\text { P. persica } \text { var. } \\
\text { nucipersica }\end{array}$ & Powdery mildew & $\begin{array}{l}\text { INRA, Montfavet, } \\
\text { France }\end{array}$ & 8 May 2008 & Yes & P. pannosa & HM579843 & HAL 2386F \\
\hline P4-2 & $\begin{array}{l}\text { P. persica } \text { var. } \\
\text { nucipersica }\end{array}$ & Powdery mildew & $\begin{array}{l}\text { INRA, Avignon, } \\
\text { France }\end{array}$ & 8 May 2008 & Yes & P. pannosa & HM579844 & HAL $2385 \mathrm{~F}$ \\
\hline P4-3 & $\begin{array}{l}\text { P. persica } \text { var. } \\
\text { nucipersica }\end{array}$ & Powdery mildew & $\begin{array}{l}\text { INRA, Avignon, } \\
\text { France }\end{array}$ & 8 May 2008 & Yes & P. pannosa & HM579845 & BPI 880512 \\
\hline P4-4 & $\begin{array}{l}\text { P. persica var. } \\
\text { nucipersica }\end{array}$ & Powdery mildew & $\begin{array}{l}\text { INRA, Avignon, } \\
\text { France }\end{array}$ & 8 May 2008 & Yes & P. pannosa & HM579847 & $\ldots$ \\
\hline
\end{tabular}

${ }^{a}$ Disease types and the powdery mildew sporulation assessed visually are also shown.

b Visible sporulating powdery mildew colonies on fruit.

${ }^{\mathrm{c}}$ Identity of fungus based on ITS sequences.

${ }^{\mathrm{d}}$ GenBank accession number of ITS sequence.

${ }^{\mathrm{e}}$ BPI = U.S. National Fungus Collections, Beltsville, MD and HAL = Herbarium of the Martin Luther University, Halle, Germany. 
nidia in the air in their environment after spraying the plants with water. All inoculated and noninoculated plants were kept in isolation in growth chambers for 2 weeks at $20^{\circ} \mathrm{C}$ and $80 \%$ relative humidity. Two weeks after inoculation, the test plants were scored visually for the presence of powdery mildew colonies and also examined under a stereomicroscope. The tests were carried out twice.

Inoculation of apple seedlings with rusty spot lesions. For these experiments, mildew-free plant material was produced in a greenhouse at University of Belgrade, Serbia, where 350 'Jonagold' apple seedlings, susceptible to $P$. leucotricha, were grown from seed in isolation under transparent plastic covers and kept there until use. To verify whether the powdery mildew mycelium on rusty spot lesions infects apple leaves, as a proof of being $P$. leucotricha, diseased Fayette fruit were collected 10 times, every 6 to 8 days from 6 May to 13 June 2009, in Serbian orchards, and the rusty spots were immediately touched to the leaves of apple seedlings transported to the peach orchards from the greenhouse in their original isolation containers. Each time, five healthy apple seedlings were inoculated with the same diseased peach fruit and three to five peach fruit with rusty spots were used as inoculum sources. Each inoculated apple seedling was placed immediately in a separate sealed container, transported back to the greenhouse, kept there for 1 month, and checked for the appearance of powdery mildew colonies every 5 to 7 days. Five noninoculated apple seedlings served as controls.

Inoculation of peach with $P$. leucotricha in the field. In spring 2009, an inoculation experiment was carried out in two Serbian peach orchards. To have large amounts of inocula, 50 'Jonagold' apple seedlings out of the 350 produced as described above were infected in early March with $P$. leucotricha collected from a single shoot of an apple tree in Bela Crkva; 50 other seedlings were infected with $P$. leucotricha collected in the same way in another Serbian locality, Vinca. The two sets of mildew-infected apple seedlings were kept in separate isolation containers and the apple powdery mildew materials were treated as distinct isolates, designated as 1_BC and 2_VI. In orchard 1 (Bela Crkva, South Banat District), 12 peach trees of 'Fayette' and 12 of 'Summerset' were included in the experiments whereas, in orchard 2 (Brestovik, Podunavlje District), 12 trees of 'Fayette' were used. From 2 April (pink-bud stage) to 20 May (5-cm-diameter fruit stage), 2 to 8 young shoots of each tree were inoculated eight times with apple powdery mildew. In both orchards, 5 of 12 trees selected for a peach cultivar received the 1 BC $P$. leucotricha inoculum and 5 others the 2_VI inoculum, while shoots on the remaining 2 trees served as untreated controls. Immediately after inoculation, the treated and control peach shoots were closed in spore-proof and moisture-resistant paper bags purchased from Litopapir Ltd. (Čačak, Serbia) (Supplementary Figure 1). Inoculations were done on the same days at both sites (Table 2). The entire surface of young shoots, including leaves, buds, flowers, or young fruit depending on the phenological stage, was inoculated using sterile brushes touched first to leaves of apple seedlings heavily infected with $P$. leucotricha and then to the peach shoots. The powdery mildew-infected apple seedlings were transported from the greenhouse to the orchards in isolation containers.

All the experimental trees were located at least $700 \mathrm{~m}$ from the closest apple trees naturally infected with powdery mildew in spring, and rusty spot disease had never been detected in these orchards during surveys conducted in previous years. As an additional measure to reduce the possibility of any natural powdery mildew infection of the uncovered shoots, all experimental peach trees and the neighboring three rows of trees were sprayed with a sulfur fungicide, $0.3 \%$ Kumulus-DF (BASF, Ludwigshaten, Germany) after each inoculation.

On 3 June 2009, 2 weeks after the last inoculation, all the branches with inoculated shoots were cut off the peach trees and transported to the laboratory, where the bags were opened and the number of fruit exhibiting symptoms of rusty spot disease was determined for each inoculation time.

\section{Results}

Detection of rusty spot and typical powdery mildew lesions on peach and nectarine fruit in Serbia and France. Lesions collected from 550 peach and nectarine fruit exhibiting symptoms of either typical powdery mildew (Fig. 1) or rusty spot (Figs. 2 and 3 ) were included in this study. In the Serbian orchards, peach rusty spot was widespread near apple orchards infected with P. leucotricha whereas typical powdery mildew colonies were found only on nectarine fruit in a single location (Male Pijace; Table 1). Sampling in southern France revealed only typical powdery mildew infections on nectarine fruit (Fig. 1; Table 1).

Morphology of typical powdery mildew and rusty spot lesions on peach and nectarine fruit. Powdery mildew lesions on

Table 2. Results of artificial inoculation of peach shoots with two isolates of Podosphaera leucotricha, 1_BC and 2_VI, carried out in two Serbian peach orchards in $2009^{\mathrm{a}}$

\begin{tabular}{|c|c|c|c|c|c|c|c|c|}
\hline \multirow[b]{2}{*}{$\begin{array}{l}\text { Location, cultivar, } \\
\text { isolate }^{\mathrm{c}}\end{array}$} & \multicolumn{8}{|c|}{ Number of fruit with rusty spots/number of all fruit on shoots inoculated on each date ${ }^{b}$} \\
\hline & $\begin{array}{c}2 \text { April } \\
\text { (pink bud) }\end{array}$ & $\begin{array}{c}\text { 8 April } \\
\text { (full bloom) }\end{array}$ & $\begin{array}{l}15 \text { April } \\
\text { (petal fall) }\end{array}$ & $\begin{array}{c}22 \text { April } \\
\text { (shuck split) }\end{array}$ & $\begin{array}{l}29 \text { April } \\
(2 \mathrm{~cm})\end{array}$ & $\begin{array}{l}6 \text { May } \\
(3 \mathrm{~cm})\end{array}$ & $\begin{array}{l}13 \text { May } \\
(4 \mathrm{~cm})\end{array}$ & $\begin{array}{l}20 \text { May } \\
(5 \mathrm{~cm})\end{array}$ \\
\hline \multicolumn{9}{|l|}{ Brestovik } \\
\hline \multicolumn{9}{|l|}{ Fayette } \\
\hline 1_BC & $1 / 13$ & $3 / 16$ & $2 / 20$ & $8 / 21$ & $5 / 26$ & $10 / 35$ & $3 / 37$ & $1 / 43$ \\
\hline 2_VI & $0 / 18$ & $0 / 17$ & $1 / 32$ & $7 / 35$ & $8 / 24$ & $7 / 42$ & $7 / 32$ & $5 / 37$ \\
\hline Control & $0 / 2$ & $0 / 9$ & $0 / 3$ & $0 / 2$ & $0 / 8$ & $0 / 12$ & $0 / 16$ & $0 / 14$ \\
\hline \multicolumn{9}{|l|}{ Bela Crkva } \\
\hline \multicolumn{9}{|l|}{ Fayette } \\
\hline 1_BC & $0 / 3$ & $2 / 18$ & $\ldots$ & $2 / 4$ & $11 / 20$ & $0 / 24$ & $6 / 27$ & $9 / 42$ \\
\hline $2 \mathrm{VI}$ & $0 / 2$ & $0 / 16$ & $4 / 35$ & $9 / 20$ & $6 / 33$ & $7 / 26$ & $8 / 39$ & $7 / 36$ \\
\hline Control & $0 / 9$ & $0 / 9$ & $0 / 8$ & $0 / 6$ & $0 / 8$ & $0 / 8$ & $0 / 12$ & $0 / 16$ \\
\hline \multicolumn{9}{|l|}{ Summerset } \\
\hline 1_BC & $0 / 15$ & $0 / 11$ & $2 / 18$ & $0 / 13$ & $9 / 24$ & $2 / 18$ & $4 / 24$ & $2 / 30$ \\
\hline 2_VI & $0 / 19$ & $0 / 16$ & $3 / 19$ & $7 / 25$ & $3 / 21$ & $2 / 19$ & $1 / 26$ & $0 / 36$ \\
\hline Control & $0 / 6$ & $0 / 4$ & $0 / 7$ & $0 / 9$ & $0 / 6$ & $0 / 6$ & $0 / 10$ & $0 / 9$ \\
\hline $\begin{array}{l}\text { Fruit with spots/ } \\
\text { total fruit }(\%)^{\mathrm{d}}\end{array}$ & $\begin{array}{c}1 / 70 \\
(1.43)\end{array}$ & $\begin{array}{c}5 / 94 \\
(5.32)\end{array}$ & $\begin{array}{l}12 / 124 \\
(9.68)\end{array}$ & $\begin{array}{c}33 / 118 \\
(27.97)\end{array}$ & $\begin{array}{r}42 / 148 \\
(28.38)\end{array}$ & $\begin{array}{r}28 / 164 \\
(17.07)\end{array}$ & $\begin{array}{r}29 / 185 \\
(15.68)\end{array}$ & $\begin{array}{c}24 / 224 \\
(10.71)\end{array}$ \\
\hline
\end{tabular}

a Inoculated shoots were kept in isolation in spore-proof and moisture-resistant paper bags on the peach trees (Supplementary Figure 1) Noninoculated shoots served as controls. The number of fruit with rusty spots was determined on each shoot on 3 June, 2 weeks after the last inoculation. The two columns with the highest values for diseased fruit are in bold.

${ }^{\mathrm{b}}$ Peach phenophases are indicated in parentheses; sizes in centimeters $=$ diameter of fruit.

c Orchard location, peach cultivar, and apple powdery mildew isolate.

$\mathrm{d}$ Total number of fruit with rusty spot/total number of inoculated fruit (percentage values). 
nectarine fruit in France and Serbia always bore numerous conidiophores and conidia typical of Oidium subgen. Fibroidium sensu Cook et al. (3), the anamorph stage of the powdery mildew genus Podosphaera (2). However, their morphology did not make possible the identification of the causal powdery mildew fungus at species level.

On rusty spot lesions collected in Serbia, powdery mildew hyphae bearing simple appressoria, and sometimes also conidia containing fibrosin bodies, characteristic of the anamorph stage of Podosphaera spp., were always detected. However, this is characteristic of the anamorph stage of several species currently belonging to the genus Podosphaera sect. Podosphaera and sect. Sphaerotheca. These studies revealed that powdery mildew mycelium, with no or little sporulation, was always present on rusty spots found on young fruit but it was not possible, using light microscopy, to identify the powdery mildew species responsible for the symptoms. On already ripened peach fruit, powdery mildew structures were sometimes absent from the surfaces of rusty spots.

Analysis of rDNA ITS sequences obtained from rusty spot and typical powdery mildew lesions. ITS sequences from four

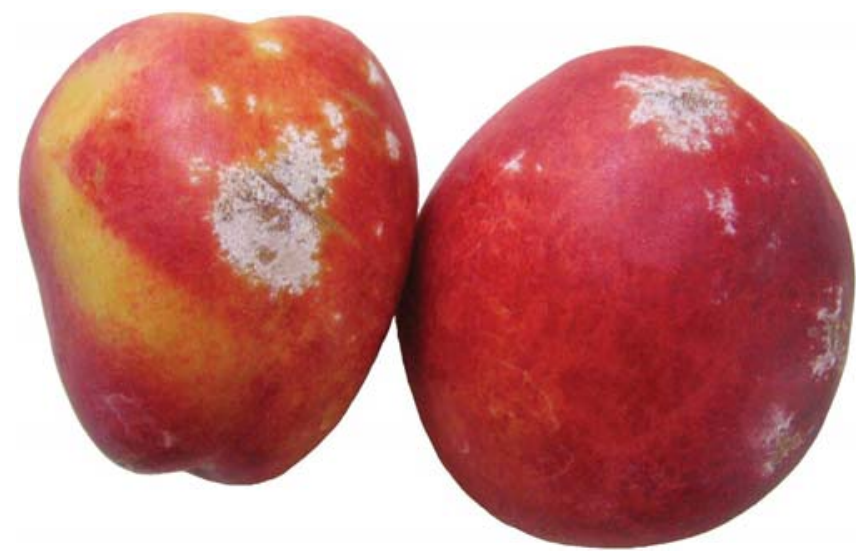

Fig. 1. Symptoms of typical powdery mildew infections, caused by Podosphaera pannosa, on 'Maillara-Big Bang ${ }^{\circledR}$ ' nectarine fruit.

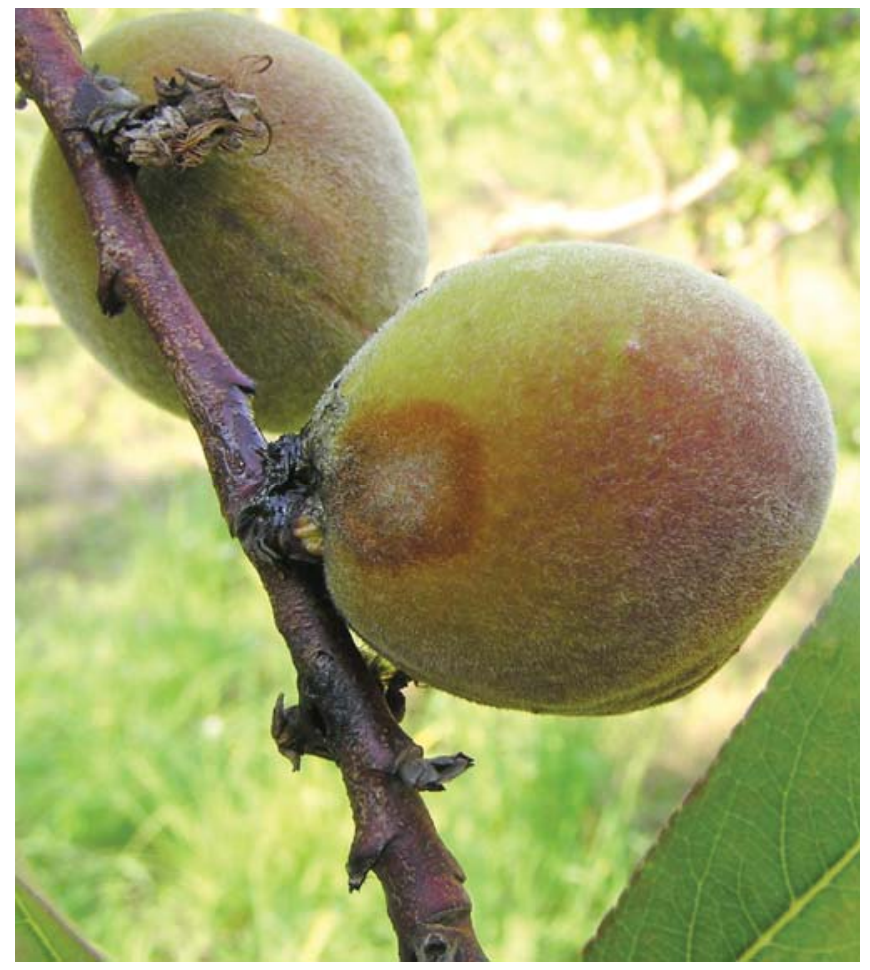

Fig. 2. Symptoms of rusty spot on young 'Fayette' peach fruit.
Serbian rusty spot samples were identical to those of $P$. leucotricha determined earlier $(6,22,30,35)$. This clearly indicated that the apple powdery mildew fungus is associated with the rusty spot disease of peach fruit. In six samples of typical powdery mildew lesions of nectarine fruit from France and Serbia, ITS sequences were identical to each other and also identical, or $99 \%$ similar, to several ITS sequences of $P$. pannosa determined earlier $(20,23,28)$. Ten ITS sequences determined in this work were deposited in GenBank (Table 1).

Inoculation of peach leaves and shoots with $P$. pannosa and $P$. leucotricha. Inoculations with $P$. pannosa consistently resulted in typical powdery mildew infections on the leaves (Fig. 4) and shoots, whereas none of the leaves and shoots inoculated with $P$. leucotricha developed symptoms. Conidia of $P$. leucotricha used in these experiments were always viable, as shown during germination tests, and conditions in the isolated greenhouse containers were favorable for the development of powdery mildew infections.

Inoculation of apple seedlings with rusty spot lesions. Inoculations of healthy apple seedlings with rusty spot lesions collected on 6,13, and 20 May in peach orchards resulted in typical powdery mildew colonies developing on 60 to $80 \%$ of the apple seedlings 6 to 9 days following inoculations. Inoculations later in

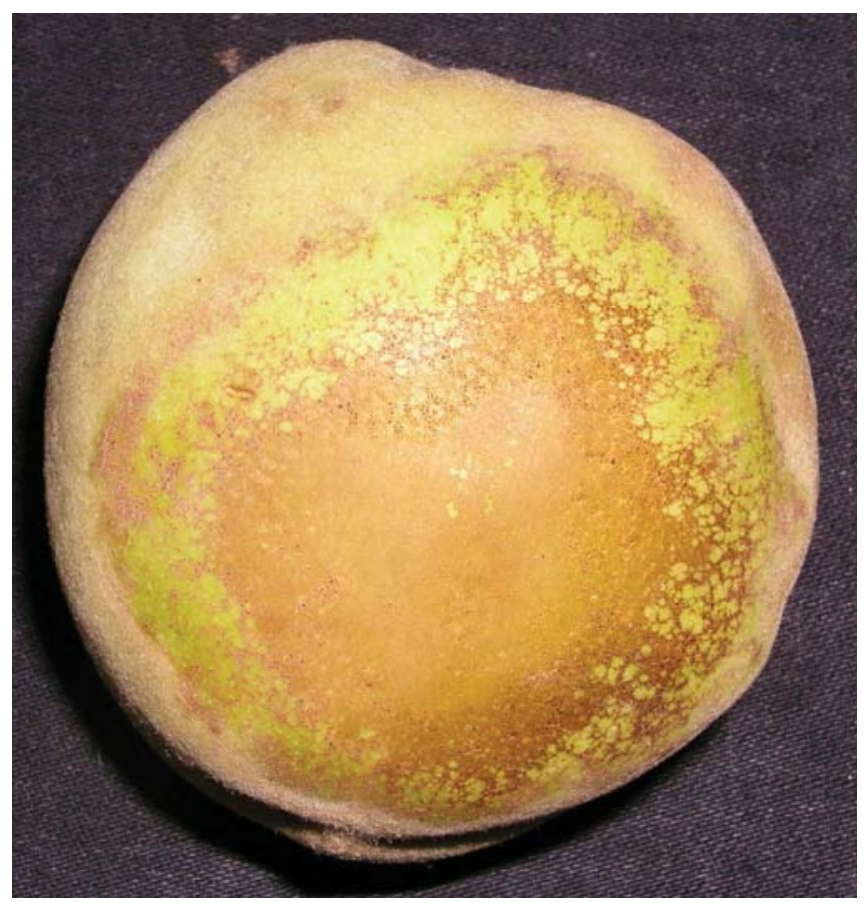

Fig. 3. Symptoms of rusty spot on mature 'Summerset' peach fruit.

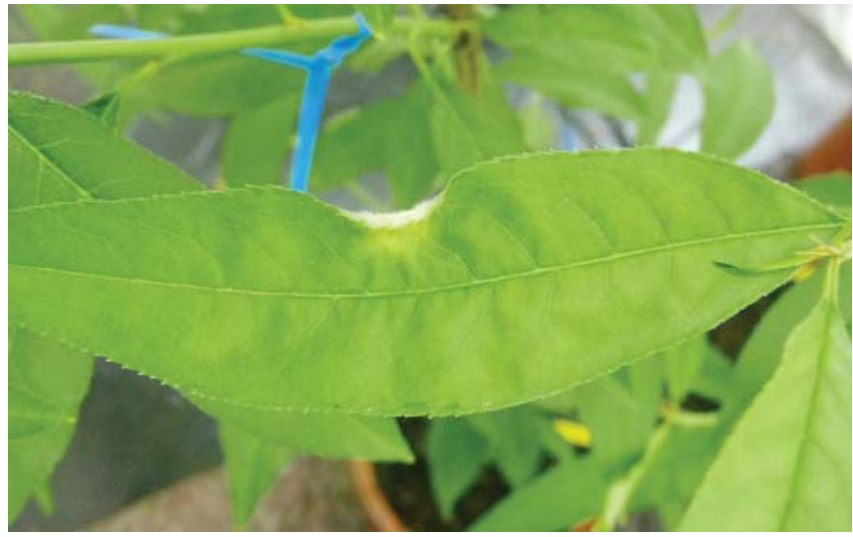

Fig. 4. Sporulating colony of Podosphaera pannosa on a peach leaf, rootstock 'GF305', following artificial inoculation. 
the season were unsuccessful. By that time, rusty spots on the fruit found in the peach orchards and used for inoculations consisted of dead tissues, and light microscopy examinations only rarely detected powdery mildew conidia or conidiophores on their surfaces.

Inoculation of peach with $P$. leucotricha in the field. Rusty spot symptoms developed on young peach fruit following inoculations with apple powdery mildew in the field. Similar results were obtained in both orchards with both 'Fayette' and 'Summerset', and also with the two P. leucotricha isolates, 1_BC and 2_VI, maintained in isolation in a greenhouse and used separately during the inoculation experiments (Table 2). In total, 175 of 1,127 inoculated peach fruit exhibited rusty spots. The highest incidence of symptomatic fruit, approximately $28 \%$, was observed on shoots inoculated in late April when these were at the shuck split phenophase or bore fruit up to $2 \mathrm{~cm}$ in diameter. Only approximately 1 to $10 \%$ of fruit developed rusty spots as a result of inoculation during pink bud, full bloom, and petal fall. Inoculations carried out when young fruit were 3 to $5 \mathrm{~cm}$ in diameter resulted in 17,15 , and $10 \%$ infection incidence; these values declined as the fruit diameter at the time of the inoculation increased (Table 2).

\section{Discussion}

Our experiments provided evidence that $P$. leucotricha is responsible for the symptoms of peach rusty spot. This was shown based on ITS sequences from rusty spot lesions, infection of apple seedlings with young rusty spot materials, and development of rusty spot symptoms following inoculations with $P$. leucotricha in a field experiment. This experiment also demonstrated that peach fruit are susceptible for only a short period of time during early development. The fact that inoculation of buds and flowers resulted in a low infection rate of the fruit may have been due to persistence of the inoculum on the inoculated shoots until the susceptible fruit epidermis appeared. Infection incidence declined as fruit developed, which suggested that the fruit epidermis became less susceptible to P. leucotricha. Rusty spots enlarge as the fruit grow but, as Ries and Royse (27) explained, this does not mean an active spread of the infection but, rather, enlargement of the epidermal cells during fruit ripening. Secondary infections (i.e., younger rusty spots close to older ones on the same shoots) have not been observed in this study and have not been reported earlier, either, although the shoots inoculated at the beginning of our field experiment should have been in contact with the $P$. leucotricha mycelium for several weeks. This also suggests that the powdery mildew mycelium sporulated only for a short time on peach fruit.

Both our field and greenhouse experiments demonstrated that $P$. leucotricha did not infect peach leaves or shoots even when disease pressure was high. Thus, it is only the young fruit epidermis that is susceptible to the attack of apple powdery mildew fungus. This was also shown in our greenhouse experiments, where peach leaves and shoots were readily infected by peach powdery mildew, $P$. pannosa (Fig. 4), but not by P. leucotricha. Typical sporulating powdery mildew lesions on peach leaves, shoots, and fruit are characteristic of $P$. pannosa infections, and rusty spot lesions are caused by $P$. leucotricha on peach fruit. Peach rusty spot appears to be the result of a hypersensitive-type plant response to a biotrophic plant pathogen which is not well specialized to this host but can establish and sporulate for a limited time on its tissues. Host range expansion has already been documented in powdery mildew fungi (34) and it is likely that peach rusty spot is an economically important case of this process.

\section{Acknowledgments}

A part of this work was supported by a grant (OTKA K73565) of the Hungarian Scientific Research Fund, an INRA-HAS bilateral project, and grants (TR31018 and III-43001) of the Ministry of Science and Technological Development of the Republic of Serbia. We gratefully acknowledge the assistance of the staff at the INRA Experimental Unit of Gotheron (in particular Dr. L. Parisi and Mr. V. Mercier) for facilitating the collection of some of the mildewed plant materials used in this work.

\section{Literature Cited}

1. Blodgett, E. C. 1941. Rusty spot of peach. Plant Dis. Rep. 25:27-28.

2. Braun, U. 1995. The Powdery Mildews (Erysiphales) of Europe. Gustav Fischer Verlag, Jena, Germany.

3. Cook, R. T. A., Inman, A. J., and Billings, C. 1997. Identification and classification of powdery mildew anamorphs using light and scanning electron microscopy and host range data. Mycol. Res. 101:975-1002.

4. Corpet, F. 1988. Multiple sequence alignment with hierarchical clustering. Nucleic Acids Res. 16:10881-10890.

5. Cunnington, J. H., Lawrie, A. C., and Pascoe, I. G. 2005. Genetic variation within Podosphaera tridactyla reveals a paraphyletic species complex with biological specialization towards specific Prunus subgenera. Mycol. Res. 119:357-362.

6. Cunnington, J. H., Takamatsu, S., Lawrie, A. C., and Pascoe, I. G. 2003 Molecular identification of anamorphic powdery mildews (Erysiphales). Australas. Plant Pathol. 32:421-428.

7. Daines, R. H., Haenseler, C. M., Brennan, E., and Leone, I. 1960. Rusty spot of peach and its control in New Jersey. Plant Dis. Rep. 44:20-22.

8. Daines, R. H., and Trout, J. R. 1977. Incidence of rusty spot of peach as influenced by proximity to apple trees. Plant Dis. Rep. 61:835-836.

9. Dolovac, N., Aleksić, G., Trkulja N., and Miletić, N. 2008. Ispitivanje mogućnosti suzbijanja prouzrokovača mrežavosti plodova na breskvi. Zbornik rezimea IX Savetovanja o zaštiti bilja. Zlatibor, str. 131-132.

10. Dolovac, N., Gavrilović, V., and Miletić, N. 2009. Control of rusty spot of peach in Serbia. In: (Abstr.) 7th Int. Peach Symp. Lleida, Spain.

11. Filatov, D. A. 2002. ProSeq: a software for preparation and evolutionary analysis of DNA sequence data sets. Mol. Ecol. Notes 2:621-624.

12. Furman, L. A., Lalancette, N., and White, J. F., Jr. 2003. Peach rusty spot epidemics: temporal analysis and relationship to fruit growth. Plant Dis. 87:366-374.

13. Furman, L. A., Lalancette, N., and White, J. F., Jr. 2003. Peach rusty spot epidemics: management with fungicide, effect on fruit growth, and the incidence-lesion density relationship. Plant Dis. 87:1477-1486.

14. Gardes, M., and Bruns, T. D. 1993. ITS primers with enhanced specificity for basidiomycetes-application to the identification of mycorrhizae and rusts. Mol. Ecol. 2:113-118.

15. Horst, R. K. 2008. Westcott's Plant Disease Handbook. Springer, New York

16. Jankovics, T., Bai, Y., Kovács, G. M., Bardin, M., Nicot, P. C., Toyoda, H., Matsuda, Y., Niks, R. E., and Kiss, L. 2008. Oidium neolycopersici: intraspecific variability inferred from AFLP analysis and relationship with closely related powdery mildew fungi infecting various plant species. Phytopathology 98:529-540.

17. Kiss, L., Jankovics, T., Kovács, G. M., and Daughtrey, M. L. 2008. Oidium longipes, a new powdery mildew fungus on petunia in the USA: a potential threat to ornamental and vegetable solanaceous crops. Plant Dis. 92:818825 .

18. Kiss, L., Takamatsu, S., and Cunnington, J. H. 2005. Molecular identification of Oidium neolycopersici as the casual agent of the recent tomato powdery mildew epidemics in North America. Plant Dis. 89:491-496.

19. Lalancette, N., Belding, R. D., Shearer, P. W., Frecon, J. L., and Tietjen, W. H. 2005. Evaluation of hydrophobic and hydrophilic kaolin particle films for peach crop, arthropod and disease management. Pest Manage. Sci. 61:25-39.

20. Leus, L., Dewitte, A., Van Huylenbroeck, J., Vanhoutte, N., Van Bockstaele, E., and Hofte, M. 2006. Podosphaera pannosa (syn. Sphaerotheca pannosa) on Rosa and Prunus spp.: characterization of pathotypes by differential plant reactions and ITS sequences. J. Phytopathol. 154:23-28.

21. Manji, B. T. 1972. Apple mildew on peach. (Abstr.) Phytopathology 62:776

22. Minnis, D., Rossman, A. Y., Clement, D., Malinowski, M. K., and Rane, K K. 2010. First report of powdery mildew caused by Podosphaera leucotricha on Callery pear in North America. Plant Dis. 94:279.

23. Mori, Y., Sato, Y., and Takamatsu, S. 2000. Evolutionary analysis of the powdery mildew fungi using nucleotide sequences of the nuclear ribosomal DNA. Mycologia 92:74-93.

24. Ogawa, J. M., Zehr, E. I., Bird, G. W., Ritchie, D. F., Uriu, K., and Uyemoto, J. K., eds. 1995. Compendium of Stone Fruit Diseases. American Phytopathological Society, St. Paul, MN.

25. Polk, D., Schmitt, D., Rizio, E., and Peterson, K. 1997. The economic impact of peach pests in New Jersey 1996-1997. N. J. State Hortic. Soc. Hortic. News 78:3-10.

26. Ries, S. M., and Royse, D. J. 1977. Rusty spot of peach in Illinois. Plant Dis. Rep. 61:317-318.

27. Ries, S. M., and Royse, D. J. 1978. Peach rusty spot epidemiology: incidence as affected by distance from a powdery mildew infected apple orchard. Phytopathology 68:896-899.

28. Saenz, G. S., and Taylor, J. W. 1999. Phylogeny of the Erysiphales (powdery mildews) inferred from internal transcribed spacer ribosomal DNA sequences. Can. J. Bot. 77:150-168

29. Shin, H. D., and La, Y. 1993. Morphology of edge lines of chained immature conidia on conidiophores in powdery mildew fungi and their taxonomic significance. Mycotaxon 46:445-451.

30. Sholberg, P. L., O'Gorman, D. T., and Bedford, K. E. 2004. Use of PCR and 
DNA hybridization for identification of pear powdery mildew caused by Podosphaera leucotricha. Can. J. Plant Pathol. 26:199-204.

31. Sprague, R., and Figaro, P. 1956. Rusty spot, powdery mildew, and healthy skin of peach fruits compared histologically. (Abstr.) Phytopathology 46:640.

32. Staden, R., Beal, K. F., and Bonfield, J. K. 2000. The Staden package, 1998. Methods Mol. Biol. 132:115-130.

33. Takamatsu, S., Shin, H.-D., Paksiri, U., Limkaisang, S., Taguchi, Y., Thi
Binh, N., and Sato, Y. 2002. Two Erysiphe species associated with recent outbreak of soybean powdery mildew: results of molecular phylogenetic analysis based on nuclear rDNA sequences. Mycoscience 43:333-341.

34. Vági, P., Kovács, G. M., and Kiss, L. 2007. Host range expansion in a powdery mildew fungus (Golovinomyces sp.) infecting Arabidopsis thaliana: Torenia fournieri as a new host. Eur. J. Plant Pathol. 117:89-93.

35. Vajna, L., and Kiss, L. 2008. First report of powdery mildew on Pyrus calleryana caused by Podosphaera leucotricha. Plant Dis. 92:176. 